\title{
PENGARUH MODEL CHILDREN'S LEARNING IN SCIENCE BERBANTUAN MEDIA AUDIO VISUAL TERHADAP KOMPETENSI PENGETAHUAN IPA SISWA
}

\author{
Luh Putri Diawati ${ }^{1}$, I Kt. Ardana ${ }^{2}$, Gst. Ngr. Sastra Agustika ${ }^{3}$ \\ 1,2,3 Jurusan Pendidikan Guru Sekolah Dasar, FIP, Universitas Pendidikan Ganesha Singaraja, Indonesia \\ email: luhputrid@yahoo.com¹, iketut.ardana@undiksha.ac.id
}

\begin{abstract}
Abstrak
Penelitian ini bertujuan untuk mengetahui pengaruh dan efektivitas model pembelajaran children's learning in science berbantuan media audio visual terhadap kompetensi pengetahuan IPA siswa kelas V SD Gugus Dr. Soetomo Kecamatan Denpasar Selatan tahun pelajaran 2017/2018. Desain penelitian ini yaitu quasi eksperimen dengan bentuk Non-Equivalent Control Group Design. Populasi penelitian ini adalah 6 kelas/kelompok siswa kelas V SD Negeri Gugus Dr.Soetomo Kecamatan Denpasar Selatan tahun pelajaran 2017/2018 dengan jumlah siswa 243 orang. Penelitian ini menggunakan 2 kelompok yang terdiri dari kelompok eksperimen dan kelompok kontrol. Kedua kelompok dipilih dengan teknik sampel kelompok (cluster). Metode pengumpulan data menggunakan metode tes. Data yang diperoleh dianalisis menggunakan uji-t dengan rumus polled varians. Rata-rata skor post test kompetensi pengetahuan IPA kelompok eksperimen yaitu 76,20 dan kelompok kontrol yaitu 70. Berdasarkan hasil analisis dengan uji $t$, diperoleh harga $t_{\text {hitung }}=2,214>t_{\text {tabel }}$ 1,988 dengan taraf signifikan $5 \%$ dan $\mathrm{dk}=85$, maka terdapat perbedaan yang signifikan kompetensi pengetahuan IPA antara kelompok eksperimen dan kelompok kontrol. Dengan demikian dapat disimpulkan bahwa model pembelajaran children's learning in science berbantuan media audio visual memiliki pengaruh yang signifikan terhadap kompetensi pengetahuan IPA siswa kelas V SD Gugus Dr. Soetomo Kecamatan Denpasar Selatan tahun pelajaran 2017/2018. Hasil perhitungan efektivitas perlakuan diperoleh nilai $\omega^{2}=0,01$ $\leq 0,055<0,09$ yaitu variansi skor kompetensi pengetahuan IPA yang disebabkan oleh model sebesar $5,5 \%$ dengan kriteria efek kecil.
\end{abstract}

Kata - kata kunci: children's learning in science, audio visual, kompetensi pengetahuan IPA

\begin{abstract}
The purpose of this study was to determined the effect and effect size of learning model of children's learning in science aided by audio-visual media for the science knowledge competency of SD Gugus Dr. Soetomo South Denpasar District's fifth grade students in academic year 2017/2018. Design of this research was quasi-experimental design with NonEquivalent Control Group Design. The population in this study was 6 classes/groups of fifth grade students at SD Gugus Dr.Soetomo South Denpasar District in academic year 2017/2018 as total of 243 students. This study used two groups consisting of experimental group and control group. Both groups were selected by cluster random technique. The method of data collection was using the test method. Data were analyzed using t-test with the polled variance formula. The average post test score of the science knowledge competency obtained by experimental students group is 76.20 and control group students is 70. Based on the analysis, the value obtained $t_{\text {count }}=2,214>t_{\text {table }}=1,988$ with significance level of $5 \%$ and $\mathrm{df}=85$, then that there are significant differences between the science knowledge competency experimental group and the control group. The conclusion is the learning model of children's learning in science aided by audio-visual media has a significant effect on the science knowledge competency of SD Gugus Dr. Soetomo South Denpasar District's fifth grade students in academic year 2017/2018. The result of the effect size obtains $\omega^{2}=0,01 \leq 0,055<0,09$ which is the variance of science knowledge competency's score causes by the model of $5,5 \%$ with the small effect criteria.
\end{abstract}

Key Word : children's learning in science, audio-visual, science knowledge competency 


\section{Pendahuluan}

Kemampuan manusia untuk selalu berfikir dan meningkatkan kualitas diri tidak terlepas dari ilmu pengetahuan dan teknologi. Pendidikan merupakan salah satu cara yang dapat ditempuh untuk terbentuknya perkembangan sumber daya manusia yang lebih baik dan berkualitas. Keberhasilan pendidikan dipengaruhi oleh perubahan dan pembaruan segala komponen pendidikan meliputi guru, siswa, kurikulum, model pembelajaran, serta sarana dan prasarana yang tepat untuk meningkatkan mutu pendidikan yang lebih baik.

Mutu pendidikan di Indonesia diupayakan secara optimal dengan penetapan kurikulum 2013 yang bertujuan untuk mempersiapkan individu yang beriman, produktif, kreatif, inovatif dan afektif. Proses pembelajaran yang demikian, menghantarkan siswa untuk mampu memahami suatu konsep dengan utuh bukan hanya sebagai pengetahuan tetapi juga diterapkan dalam kehidupan sehari-hari. Upaya untuk mewujudkan proses pembelajaran yang ditetapkan tersebut, hendaknya setiap komponen mampu menciptakan proses pembelajaran yang efektif dan efisien serta pembelajaran yang bermakna bagi siswa.

Penerapan pembelajaran kurikulum 2013 dengan pembelajaran tematik terpadu yaitu pemaduan beberapa mata pelajaran menjadi sebuah tema sehingga siswa dapat memahami suatu konsep dengan utuh. Salah satu mata pelajaran yang terpadu yaitu mata pelajaran IImu Pengetahuan Alam (IPA). Sulistyowati dan Wisudawati (2015:22) menyatakan bahwa "IPA merupakan rumpun ilmu, memiliki karakteristik khusus yaitu mempelajari fenomena alam yang faktual (factual), baik berupa kenyataan (reality) atau kejadian (events) dan hubungan sebab akibatnya". Selanjutnya Susanto (2016:167) menyatakan bahwa "sains atau IPA adalah usaha manusia dalam memahami alam semesta melalui pengamatan yang tepat pada sasaran, serta menggunakan prosedur, dan dijelaskan dengan penalaran sehingga mendapatkan suatu kesimpulan". Sehingga dapat disimpulkan bahwa IPA merupakan ilmu pengetahuan yang dipelajari dari gejala alam yang berupa fakta-fakta, konsep-konsep atau prinsip-prinsip dari hasil percobaan atau pengamatan sehingga diperoleh suatu kesimpulan. Menurut Sulistyowati dan Wisudawati (2015) hakikat pembelajaran IPA diklasifikasikan menjadi empat yaitu produk, proses, sikap dan aplikasi. Hakikat IPA tersebut, dapat dipahami bahwa pembelajaran IPA didasarkan pada penumbuhan sikap ilmiah siswa terhadap konsep-konsep IPA melalui pengamatan maupun penyelidikan sederhana dan bukan hafalan sehingga pembelajaran IPA yang berlangsung dapat bermakna dan diterapkan dalam kehidupan sehari-hari.

Kompetensi pengetahuan IPA di sekolah dasar adalah perubahan perilaku siswa yang mencerminkan kemampuan siswa terhadap pembelajaran IPA dari segi pengetahuan setelah mengalami proses belajar yang meliputi kemampuan berfikir yaitu mengingat, memahami, menerapkan, menganalisis, mengevaluasi dan mencipta.

Berdasarkan informasi pada hari senin, 08 Januari 2018 yang diperoleh dari ketua gugus, kepala sekolah dan seluruh guru kelas V di SD Gugus Dr. Soetomo Kecamatan Denpasar Selatan Tahun Pelajaran 2017/2018, dalam pelaksanaan pembelajaran tematik khususnya pengintegrasian yang memuat mata pelajaran IPA belum dapat terlaksana dengan optimal. Permasalahan terletak pada masih kurangnya kemampuan siswa dalam mengkonstruksi pengetahuan awal yang dimilikinya dengan pengetahuan baru yang dipelajarinya. Pelaksanaan pembelajaran yang cenderung monoton karena penerapan model pembelajaran dan media pembelajaran khususnya media pembelajaran audio visual yang kurang bervariasi dan berorientasi pada siswa menyebabkan siswa kurang aktif dalam proses pembelajaran. Suasana belajar yang demikian menyebabkan pembelajaran kurang bermakna sehingga konsep yang dimiliki kurang dapat diaplikasikan dalam kehidupan sehari-hari dengan tepat.

Salah satu usaha yang dapat dilakukan adalah dengan menerapkan model pembelajaran yang inovatif dan media pembelajaran untuk mendukung proses pembelajaran agar situasi pembelajaran menjadi aktif dan bermakna bagi siswa. Salah satu model pembelajaran yang mendukung yaitu model pembelajaran children's learning in science berbantuan media audio visual.

Model pembelajaran children's learning in science yang disingkat CLIS merupakan model yang dilandasi konstruktivisme yang dapat membantu siswa memperoleh pembelajaran yang 
bermakna. Model pembelajaran CLIS merupakan model pembelajaran yang melibatkan siswa secara aktif dalam berbagai aktivitas belajar sehingga siswa dapat menggali pengetahuannya, menyusun gagasannya, mengkonstruksi gagasan baru melalui pengamatan dan percobaan serta dapat menerapkan gagasan tersebut. Menurut Samatowa (2016) model CLIS terdiri atas lima tahapan atau langkah utama yaitu orientasi atau orientation (a), pemunculan gagasan atau elicitation of ideas (b), penyusunan ulang gagasan atau restructuring of ideas (c), penerapan gagasan atau application of ideas (d), pemantapan gagasan atau review change ideas (e). Langkah penyusunan ulang gagasan dibedakan menjadi tiga bagian, yaitu pengungkapan dan pertukaran gagasan atau clarification and axchange (i), pembukaan pada situasi konflik atau exposure to conflict situation (ii) dan konstruksi gagasan baru dan evaluasi atau construction of new ideas and evaluation(iii). Proses belajar dengan model ini dapat melibatkan siswa untuk aktif dalam mengkonstruksi pengetahuan yang dimilikinya dan berpengaruh terhadap kompetensi pengetahuan yang dimilikinya.

Media pembelajaran yang dapat mendukung model pembelajaran CLIS salah satunya yaitu media audio visual. "Media audio visual merupakan media yang terdiri atas media auditif atau mendengar dan visual atau melihat" (Wati, 2016:43). Penggunaan media audio visual dapat menampilkan unsur gambar atau suara secara terpadu pada saat mengomunikasikan pesan atau informasi (Wati, 2016). Media audio visual terbagi menjadi dua macam, yaitu audio visual murni dan audio visual tidak murni. Audio visual murni merupakan sebuah media yang memiliki unsur suara maupun unsur gambar yang berasal dari satu sumber, seperti film bersuara, video dan televisi. Sementara audio visual tidak murni merupakan sebuah media yang unsur suara dan unsur gambarnya berasal dari sumber yang berlainan, seperti slide/film strip (Wati, 2016).

Berdasarkan uraian tersebut, maka dilakukan penelitian yang berjudul "Pengaruh Model Pembelajaran Children's Learning In Science Berbantuan Media Audio Visual Terhadap Kompetensi Pengetahuan IPA Siswa Kelas V SD Gugus Dr. Soetomo Kecamatan Denpasar Selatan". Penelitian ini bertujuan untuk mengetahui pengaruh yang signifikan kompetensi pengetahuan IPA siswa yang dibelajarkan dengan model pembelajaran CLIS berbantuan media audio visual dan untuk mengetahui persentase besar pengaruh (efektivitas) perlakuan yang diberikan.

\section{Metode}

Penelitian ini merupakan penelitian kuantitatif, yaitu menggunakan desain eksperimen semu (quasi experiment design). Sugiyono (2016:77), menjelaskan bahwa "quasi experimental design mempunyai kelompok kontrol namun tidak dapat berfungsi sepenuhnya untuk mengontrol variabel-variabel luar yang mempengaruhi pelaksanaan eksperimen". Bentuk desain eksperimen semu yang digunakan dalam penelitian ini adalah Non-Equivalent Control Group Design. Rancangan dalam penelitian ini diformulasikan sebagai berikut.

\begin{tabular}{|c|c|c|}
\hline $\mathrm{O}_{1}$ & $X$ & $\mathrm{O}_{2}$ \\
\hline $\mathrm{O}_{3}$ & & $\mathrm{O}_{4}$ \\
\hline
\end{tabular}

\section{Gambar 1. Rancangan Non-Equivalent Control Group Design}

Rancangan penelitian ini melibatkan dua kelompok kelas yang diberikan pre test dan post test. "Pemberian pre test biasanya digunakan untuk mengukur equivalensi atau penyetaraan kelompok" (Dantes, 2017:2018). 
"Populasi adalah wilayah generalisasi yang terdiri dari obyek atau subyek yang mempunyai kualitas dan karakteristik tertentu yang ditetapkan oleh peneliti untuk dipelajari dan kemudian ditarik kesimpulan" (Sugiyono, 2016:80). Sedangkan menurut Setyosari (2015:221) "Populasi itu merupakan kelompok yang lebih besar jumlahnya dan biasanya yang dipakai untuk menggeneralisasi hasil penelitian". Jadi dapat disimpulkan bahwa populasi adalah wilayah generalisasi yang terdiri atas obyek atau subyek yang memiliki kualitas dan karakteristik tertentu yang ditentukan peneliti yang kemudian diteliti untuk dipelajari dan ditarik kesimpulan sehingga dapat digunakan untuk menggeneralisasikan hasil penelitian. Populasi penelitian ini yaitu 6 kelas/kelompok siswa kelas V SD Negeri Gugus Dr.Soetomo Kecamatan Denpasar Selatan Tahun Pelajaran 2017/2018 dengan jumlah siswa 243 orang.

"Sampel ialah sebagian dari populasi yang diambil, yang dianggap mewakili seluruh populasi dan diambil dengan menggunakan teknik tertentu" (Agung, 2014:69). Sedangkan menurut Setyosari (2015:221), "sampel merupakan sejumlah kelompok kecil yang mewakili populasi untuk dijadikan sebagai objek penelitian". Sehingga dapat disimpulkan bahwa sampel merupakan bagian atau kelompok kecil dari jumlah dan karakteristik yang dimiliki populasi yang dianggap representatif (mewakili) yang diambil dengan teknik tertentu.

Teknik sampling yang digunakan dalam menentukan sampel adalah teknik sampel kelompok. "Teknik sampel kelompok atau rumpun (cluster) digunakan apabila populasi atau sampel yang tersedia adalah berupa unit-unit rumpun dalam populasi” (Setyosari, 2015:224). Teknik sampel kelompok dilakukan untuk mengambil sampel dari kelompok-kelompok yang telah ditentukan seperti menggunakan kelas atau kelompok. Teknik acak/rambang tidak dapat dilakukan untuk mengambil secara acak individu pada kelas yang sudah terbentuk, melainkan diambil dari kelompok-kelompok yang telah ditentukan dan tersedia. Hal ini juga dapat mengurangi pengaruh-pengaruh dari keadaan siswa mengetahui dirinya dilibatkan dalam eksperimen sehingga penelitian ini benar-benar menggambarkan pengaruh perlakuan yang diberikan.

Penentuan sampel yang dipilih menjadi kelompok kontrol dan kelompok eksperimen dilakukan dengan cara pengundian. Pengundian dilakukan agar semua anggota populasi memiliki kesempatan yang sama untuk dipilih menjadi sampel penelitian dan memenuhi syarat representatif. Setelah dilakukan pengundian diperoleh hasil dua kelompok yang terpilih sebagai sampel penelitian yaitu kelas VB di SD Negeri 9 Sesetan yang berjumlah 42 orang dan kelas V di SD Negeri 14 Sesetan yang berjumlah 45 orang. Kedua kelompok yang keluar dalam undian kemudian diberi pre test dengan tujuan untuk menyetarakan kedua kelompok secara akademik. Hasil nilai atau skor pre test yang diperoleh dianalisis menggunakan uji t untuk memperoleh kelas yang setara. Kedua kelompok yang dinyatakan setara kemudian dilakukan pengundian kembali untuk menentukan kelompok eksperimen dan kelompok kontrol. Berdasarkan hasil pengudian diperoleh kelas VB SD Negeri 9 Sesetan sebagai kelompok eksperimen yang dibelajarkan dengan model pembelajaran children's learning in science berbantuan media audio visual dan kelas V SD Negeri 14 Sesetan sebagai kelompok kontrol yang dibelajarkan dengan pembelajaran konvensional yaitu pendekatan saintifik.

Pada suatu penelitian eksperimen perlu dilakukan pengendalian terhadap validitas penelitian. "Validitas penelitian adalah kemampuan peneliti untuk mengungkapkan secara tepat yang ingin diteliti" (Dantes, 2017:3). Jadi validitas adalah faktor-faktor/variabel-variabel lain yang dapat mempengaruhi hasil penelitian. Validitas yang berkaitan dengan penelitian dapat dibedakan menjadi dua, yaitu validitas internal dan validitas eksternal. Beberapa ancaman yang dapat dikontrol dalam penelitian ini dan cara untuk mengontrol pengaruhnya dijelaskan sebagai berikut: (1) karakteristik subjek, dikendalikan dengan penyetaraan kelompok eksperimen dan kelompok kontrol dengan uji t dan dengan menggunakan jenjang kelas yang sama yaitu kelas $V$, (2) instrumentasi, dikendalikan dengan pemilihan instrumen pengumpulan data yang tepat yaitu tes pilihan ganda biasa untuk menghindari ancaman akibat faktor penilai yang subjektivitas sehingga memberikan standar penilaian yang berbeda dan instrumen diujicobakan terlebih dahulu, (3) testing, dikendalikan dengan soal soal yang berbeda yaitu pre test digunakan untuk mengukur kesetaraan sampel yang memuat materi yang pernah dipelajari dan post test memuat materi yang dipelajari saat perlakuan, (4) sejarah, dikendalikan dengan 
guru yang melakukan perlakuan pada kelompok eksperimen dan kelompok kontrol memiliki kualifikasi jenjang pendidikan yang sama, (5) kematangan, dikendalikan dengan jangka waktu pelaksanaan penelitian yang tidak terlalu lama, dan (6) sikap subjek, dikendalikan dengan menggunakan guru kelas dalam proses pembelajaran. Validitas eksternal yang dikontrol terdiri dari interaksi antara seleksi subjek dengan perlakuan, dikendalikan dengan teknik sampling yang digunakan yaitu sampel kelompok dengan melakukan pengundian setiap kelas yang terdapat pada populasi sehingga setiap kelas dalam populasi memiliki peluang yang sama untuk dijadikan sampel penelitian. Sampel tersebut bersifat representatif (mewakili) terhadap populasi dan ancaman interaksi setting dengan perlakuan, dikendalikan dengan membatasi populasi dengan tujuan agar lebih mudah mengontrol ancaman validitas eksternal.

Data yang digunakan dalam penelitian ini yaitu kompetensi pengetahuan IPA siswa yang diukur dengan menggunakan instrumen penelitian yaitu tes objektif dalam bentuk pilihan ganda biasa. Arikunto (2017:183) "tes pilihan ganda adalah tes yang terdiri atas bagian keterangan (steam) dan bagian kemungkinan jawaban atau alternatif (options). Kemungkinan jawaban terdiri atas satu jawaban benar yaitu kunci jawaban dan beberapa pengecoh (distractor)". Sebelum digunakan, tes tersebut terlebih dahulu di uji validitas, uji reliabilitas, uji daya beda dan uji tingkat kesukaran. Instrumen tes diujicobakan pada siswa kelas $\mathrm{V}$ pada populasi penelitian di luar sampel dengan responden yaitu siswa kelas VB SD Negeri 12 Sesetan sebanyak 29 orang dan siswa kelas V SD Negeri 4 Sesetan sebanyak 52 orang dengan total responden 81 orang. Suatu instrumen dikatakan valid apabila tes tersebut dapat dengan tepat mengukur apa yang hendak di ukur. Uji validitas yang digunakan dalam penelitian ini yaitu uji validitas isi dan uji validitas butir. "Validitas isi adalah validitas dari segi isinya atau apabila mengukur tujuan khusus tertentu yang sejajar dengan isi atau materi pelajaran yang diberikan" (Arikunto, 2017:82). Uji validitas isi dalam penelitian ini merujuk pada soal muatan materi IPA yang disusun sesuai dengan kompetensi dasar, indikator dan butir tes yang dituangkan dalam bentuk kisi-kisi. Uji validitas butir tes digunakan untuk mengetahui apakah soal yang diberikan terlalu buruk, kurang tepat atau terlalu sulit (Yusuf, 2015). Uji validitas butir tes kompetensi pengetahuan IPA dalam bentuk tes objektif pilihan ganda biasa digunakan rumus korelasi point biserial (rpbi). Berdasarkan perhitungan, dari 50 butir tes yang diujikan diperoleh 36 butir tes yang valid dan 14 butir tes yang tidak valid. Soal yang valid kemudian dilakukan uji daya beda yaitu "kemampuan suatu soal yang membedakan antara siswa yang pandai (berkemampuan tinggi) dengan siswa yang bodoh (berkemampuan rendah)" (Arikunto, 2017:226). Bedasarkan hasil perhitungan, dari 36 soal yang valid diperoleh 1 butir soal dengan kriteria jelek, 13 butir soal dengan kriteria cukup, 21 butir soal dengan kriteria baik dan 1 butir soal dengan kriteria baik sekali. Butir soal dengan kriteria jelek tidak digunakan sehingga soal yang memenuhi syarat untuk dilakukan uji selanjutnya yaitu 35 butir soal. Selanjutnya 35 butir soal dilakukan uji tingkat kesukaran butir tes dan perangkat tes yaitu kesanggupan responden yang menjawab benar soal yang diberikan. Proporsi jumlah soal berada dalam kurva normal yaitu sebagian besar soal berada pada kategori sedang, sebagian lagi termasuk ke dalam kategori mudah dan sukar dengan proporsi seimbang. Berdasarkan hasil perhitungan indeks kesukaran perangkat tes yaitu 0,39 sehingga indeks kesukaran perangkat tes termasuk dalam kriteria sedang. Berdasarkan perhitungan indeks kesukaran butir tes diperoleh 7 butir soal dengan kriteria sukar, 20 butir soal dengan kriteria sedang dan 8 butir soal dengan kriteria mudah. Butir soal tersebut kemudian di uji reliabilitas dengan menggunakan rumus Kunder Richadson (KR-20). "alat ukur dikatakan reliabel, apabila alat ukur itu diujikan kepada objek atau subjek yang sama secara berulang-ulang hasilnya tetap sama , konsisten, stabil atau relatif sama (tidak berbeda secara statistik)" (Yusuf, 2015:74). Berdasarkan hasil perhitungan dari 35 butir soal yang di uji reliabilitas diperoleh diperoleh nilai $r_{11}$ sebesar 0,82 . Sehingga tes kompetensi pengetahuan IPA layak digunakan sebagai instrumen penelitian dengan kriteria reliabilitas tinggi. Dari hasil uji validitas, uji daya beda, uji tingkat kesukaran dan uji reliabilitas maka dari 50 soal yang diujicobakan diperoleh 35 butir soal yang layak digunakan sebagai instrumen penelitian.

Teknik yang digunakan untuk menganalisis kompetensi pengetahuan IPA siswa dalam penelitian ini adalah dengan menggunakan statistik inferensial yaitu dengan uji beda mean (uji t) dengan rumus polled varians. Sebelum dianalisis menggunakan uji t kedua kelompok diuji 
prasyarat yaitu uji normalitas sebaran data menggunakan Uji Kolmogorov-Smirnov dan uji homogenitas variansi menggunakan Uji F. Hasil analisis dilanjutkan dengan mengukur persentase efek (efektivitas) perlakuan dengan omega square $\left(\omega^{2}\right)$. Pengujian efektivitas penting dilakukan untuk melengkapi informasi hasil uji analisis signifikansi statistik yaitu untuk mengetahui besarnya perbedaan/korelasi. Kriteria besarnya persentase pengaruh (Efektivitas) diklasifikasikan sebagai efek kecil jika $\omega^{2}=0,01 \leq \omega^{2}<0,09$, efek sedang jika $\omega^{2}=0,09 \leq \omega^{2}$ $<0,25$ dan efek besar jika $\omega^{2}=\omega^{2} \geq 0,25$.

\section{Hasil dan Pembahasan}

Objek pada penelitian ini adalah kompetensi pengetahuan IPA. Data yang dianalisis pada penelitian ini adalah data hasil pre test dan post test kompetensi pengetahuan IPA kelompok eksperimen dan data hasil pre test dan post test kompetensi pengetahuan IPA kelompok kontrol. Data pre test digunakan untuk mengukur kesetaraan kelompok kelas. Post test diberikan untuk mengetahui perbedaan kompetensi pengetahuan IPA siswa kelompok eksperimen dan kelompok kontrol.

Hasil data pre test dan post test kelompok eksperimen dikelompokkan dalam grafik steam and leaf sebagai berikut.

\begin{tabular}{r|c|l}
$\begin{array}{c}\text { Kelompok Kontrol } \\
\text { Leaves (Pre Test) }\end{array}$ & Steams & $\begin{array}{c}\text { Kelompok } \\
\text { Kontrol } \\
\text { Leaves (Post Test) }\end{array}$ \\
\hline- & 0 & - \\
- & 1 & - \\
- & 2 & - \\
- & 3 & - \\
3000 & 4 & 999999 \\
77733330 & 5 & 447777 \\
7773300000 & 6 & 6666666 \\
777333333333333000000 & 7 & 4444444777777777 \\
70 & 8 & 000066699 \\
- & 9 & 1 \\
- & 10 & -
\end{tabular}

Gambar 3. Grafik steam and leaf data pre test dan post test kelompok kontrol

Berdasarkan uji normalitas data menggunakan Kolmogorov-Smirnov diperoleh nilai maksimum $\left|F_{\mathrm{T}}-\mathrm{F}_{\mathrm{S}}\right|=0.1031$ dan nilai tabel Kolmogorov-Smirnov untuk taraf signifikansi $5 \%$ $(\alpha=0,05)=0,2099$ karena nilai maksimum $\left|F_{T}-F_{S}\right| \leq$ nilai tabel Kolmogorov-Smirnov maka data kelompok eksperimen berdistribusi normal. Sedangkan nilai maksimum $\left|F_{T}-F_{S}\right|=$ 0.1815 dan nilai tabel Kolmogorov-Smirnov untuk taraf signifikansi $5 \%(\alpha=0,05)=0,2027$ karena nilai maksimum $\left|\mathrm{F}_{\mathrm{T}}-\mathrm{F}_{\mathrm{S}}\right| \leq$ nilai tabel Kolmogorov-Smirnov maka data kelompok kontrol berdistribusi normal.

Kedua kelompok yang dinyatakan berdistribusi normal kemudian dilakukan uji homogenitas variansi dan diperoleh hasil $F_{\text {hitung }}=1,02$ dan $F_{\text {tabel }}=1,66$. Dengan taraf signifikansi $5 \%(\alpha=0,05)$ dengan derajat kebebasan pembilang $42-1=41$ dan derajat kebebasan penyebut 45-1 $=44$. Maka nilai $F_{\text {hitung }}=1,02<F_{\text {tabel }}=1,66$ yang disimpulkan bahwa data kedua kelompok memiliki variansi yang homogen.

Berdasarkan hasil uji prasyarat, diperoleh data kedua kelompok berdistribusi normal dan homogen sehingga dapat dilanjutkan dengan menguji hipotesis dengan rumus polled varians 
dengan jumlah anggota sampel $\mathrm{n}_{1} \neq \mathrm{n}_{2}$. Hipotesis penelitian yang diuji dalam penelitian ini adalah hipotesis nol $\left(\mathrm{H}_{0}\right)$ yaitu tidak terdapat perbedaan yang signifikan kompetensi pengetahuan IPA siswa antara kelompok eksperimen dan kelompok kontrol pada siswa kelas $\mathrm{V}$ SD Gugus Dr. Soetomo Kecamatan Denpasar Selatan. Berikut disajikan rekapitulasi hasil analisis data dengan menggunakan uji t pada Tabel 1.

Tabel 1. Rekapitulasi Uji t Kelompok Sampel Penelitian

\begin{tabular}{lccccccc}
\hline Kelompok Sampel & $\mathrm{n}$ & Variansi & $\bar{X}$ & $\mathrm{dk}$ & $\mathrm{t}_{\text {hitung }}$ & $\mathrm{t}_{\text {tabel }}$ & Kesimpulan \\
Eksperimen & 42 & 158,29 & 76,20 & 85 & 2,214 & 1,988 & $\mathrm{H}_{0}$ ditolak \\
Kontrol & 45 & 155,23 & 70 & & & & \\
\hline
\end{tabular}

Berdasarkan rekapitulasi uji hipotesis dengan uji t dijelaskan bahwa data kelompok eksperimen, diketahui data berpusat di sekitar nilai 76,20 dengan penyimpangan skor terhadap rata-rata sebesar 158,29 dan pada kelompok kontrol data berpusat di sekitar nilai 70 dengan penyimpangan skor terhadap rata-rata sebesar 155,23.

Rata-rata/mean skor post test kompetensi pengetahuan IPA kelompok eksperimen yaitu 76,20 dan kelompok kontrol yaitu 70 . Hasil analisis uji t diperoleh $t_{\text {hitung }}=2,214$ dan untuk taraf signifikansi $5 \%$ dengan $\mathrm{dk}=(42+45-2)=85$ diperoleh $t_{\text {tabel }}=1,988$. Dengan demikin maka, nilai $t_{\text {hitung }}=2,214>t_{\text {tabel }}=1,988$, maka $\mathrm{H}_{0}$ ditolak dan $\mathrm{H}_{\mathrm{a}}$ diterima. Hasil perhitungan ini menunjukkan bahwa terdapat perbedaan yang signifikan kompetensi pengetahuan IPA siswa antara kelompok eksperimen dan kelompok kontrol. Sehingga disimpulkan bahwa terdapat pengaruh yang signifikan model pembelajaran CLIS berbantuan media audio visual terhadap kompetensi pengetahuan IPA siswa kelas V SD Gugus Dr.Soetomo Kecamatan Denpasar Selatan Tahun Pelajaran 2017/2018.

Hal ini disebabkan oleh kegiatan pembelajaran dengan menggunakan model pembelajaran CLIS berbantuan media audio visual melibatkan siswa secara aktif dalam berbagai aktivitas belajar sehingga siswa dapat menggali pengetahuannya melalui kegiatan yang meliputi, menyusun dan mengkonstruksi gagasan baru, serta menerapkan gagasan tersebut melalui hasil pengamatan dan percobaan yang dilakukan.

Kegiatan pembelajaran yang menggunakan model pembelajaran CLIS berbantuan media audio visual menerapkan lima langkah belajar. Langkah pertama yaitu orientasi atau orientation dapat memusatkan perhatian siswa mengenai materi yang dipelajari, selain itu pada tahap ini siswa dilatih untuk mengomunikasikan pendapat yang dimilikinya. Langkah kedua pemunculan gagasan atau elicitation of ideas yaitu siswa diarahkan oleh guru untuk aktif menggali pengetahuan awal yang dimilikinya sehingga siswa mengingat fenomena yang pernah dialami dalam kehidupan sehari-hari yang kemudian dijadikan konsep awal yang diperkuat dengan percobaan/pengamatan. Pada awal perlakuan, sedikit siswa yang bersedia menyampaikan gagasan yang dimilikinya, siswa ragu dengan jawaban yang disampaikan namun pada perlakuan kedua dan seterusnya siswa mulai percaya diri untuk memaparkan fenomena yang pernah dialami dalam kehidupan sehari-hari yang berkaitan dengan materi. Langkah ketiga penyusunan ulang gagasan atau restructuring of ideas dibagi menjadi tiga tahap yaitu pada tahap pertama pengungkapan dan pertukaran gagasan atau clarification and axchange, siswa mendiskusikan dengan kelompok mengenai konsep awal yang dimilikinya dan siswa berperan aktif menemukan konsep sendiri. Di awal perlakuan tidak semua siswa mampu aktif untuk mengungkapkan dan mendiskusikan konsep awal yang dimilikinya, hal ini dikarenakan siswa masih asing dengan langkah tersebut serta siswa yakin dengan konsep awalnya sehingga enggan mendiskusikannya dengan kelompok. Pada tahap kedua pembukaan pada situasi konflik atau exposure to conflict situation yaitu konsep awal yang telah didiskusikan dengan kelompok diuji kebenarannya dengan pengamatan/percobaan serta membaca buku sehingga materi pembelajaran lebih bermakna. Pada tahap ini siswa sangat antusias karena konsep yang belum diketahuinya dan masih keliru kemudian dipahami melalui percobaan selain itu melalui tahap ini siswa diberikan dorongan/ dimotivasi yang dibantu oleh guru untuk membaca 
buku sehingga dapat menemukan konsep barunya sendiri. Tahap ketiga konstruksi gagasan baru dan evaluasi atau construction of new ideas and evaluation yaitu siswa mencocokkan gagasan awal dengan gagasan baru yang diperoleh sehingga pada langkah keempat yaitu penerapan gagasan atau application of ideas siswa sudah dapat menerapkan gagasan baru tersebut pada fenomena yang terjadi dalam kehidupan sehari-hari. Langkah terakhir yaitu pemantapan gagasan atau review change ideas yaitu siswa membandingkan konsep awal dengan konsep baru dan mengubah konsep awal yang keliru menjadi konsep baru yang ilmiah. Langkah ini lebih banyak dibantu oleh guru untuk menghantarkan pada penjelasan bahwa siswa yang memiliki konsep keliru dapat memperbaiki menjadi konsep ilmiah. Model pembelajaran ini dipadukan dengan media audio visual yang membuat siswa lebih memahami materi dan materi dijelaskan lebih konkret. Hal ini membuat pembelajaran lebih bermakna. Selain itu pada proses pembelajaran siswa lebih bersemangat dalam menyampaikan gagasan awal karena guru menstimulus pengetahuan siswa dengan bantuan video yang berkaitan dengan materi.

Berbeda dengan pembelajaran yang berlangsung pada kelompok kontrol. Kegiatan pembelajaran pada kelompok kontrol berjalan kurang optimal karena hanya menerapkan pembelajaran dengan pendekatan saintifik. Pendekatan saintifik yaitu pembelajaran yang tidak menerapkan sintak belajar namun menggunakan lima pengalaman belajar yaitu mengamati, menanya, mengumpulkan informasi, mengasosiasi, dan mengomunikasikan yang pelaksanaannya tidak tersusun secara sistematis. Hal tersebut membuat pembelajaran terasa monoton sehingga siswa kurang aktif dalam proses pembelajaran. Siswa kurang memahami materi karena media pembelajaran berupa gambar pada buku siswa. Pembelajaran yang demikian membuat konsep kurang dapat dipahami siswa sehingga pembelajaran kurang bermakna.

Pembelajaran menggunakan model pembelajaran CLIS berbantuan media audio visual ini memiliki keunggulan yakni (a) siswa menjadi aktif serta dapat mengkonstruksi gagasan yang dimiliki melalui pengamatan dan percobaan yang dipadukan dengan media pembelajaran audio visual, (b) siswa terbiasa belajar mandiri untuk memecahkan masalah, (c) siswa terlibat langsung dalam menemukan konsep sehingga pembelajaran lebih bermakna, dan (d) penyampaian materi oleh guru lebih mudah dipahami siswa sehingga proses belajar lebih efektif.

Setelah dilakukan analisis hipotesis menggunakan uji t maka dilanjutkan dengan pengujian untuk menentukan persentase pengaruh (efektivitas) perlakuan dengan rumus omega square $\left(\omega^{2}\right)$. Berdasarkan hasil perhitungan tersebut, diperoleh nilai kriteria $\omega^{2}=0,055$. Sesuai dengan kriteria persentase besar pengaruh (Efektivitas), $\omega^{2}=0,01 \leq 0,055<0,09$. Sehingga dapat disimpulkan bahwa dengan penerapan model pembelajaran CLIS berbantuan media audio visual memiliki persentase pengaruh (efektivitas) sebesar 5,5\% yaitu dengan efek kecil. Hal ini menunjukkan bahwa sebesar 5,5\% penerapan model pembelajaran CLIS berbantuan media audio visual menyebabkan perbedaan variansi skor kompetensi pengetahuan IPA. Hal tersebut terjadi karena di luar model pembelajaran yang diterapkan terdapat faktor-faktor lain yang mempengaruhi kompetensi pengetahuan IPA.

\section{Simpulan dan Saran}

Berdasarkan perhitungan, uji hipotesis dan pembahasan hasil penelitian, diperoleh rata-rata skor post test kompetensi pengetahuan IPA kelompok eksperimen yaitu 76,20 dan kelompok kontrol yaitu 70 . Hasil uji $t$ diperoleh $I t_{\text {hitung }}=2,214$, sedangkan $t_{\text {tabel }}=1,988$ pada taraf signifikansi $5 \%$ dengan $d k=85$. Oleh karena harga $t_{\text {hitung }}=2,214>t_{\text {tabel }}=1,988$, maka $H_{0}$ ditolak dan $\mathrm{H}_{\mathrm{a}}$ diterima. Hal ini berarti terdapat perbedaan yang signifikan kompetensi pengetahuan IPA siswa kelompok eksperimen yang dibelajarkan dengan model pembelajaran CLIS berbantuan media audio visual dan kelompok kontrol yang dibelajarkan dengan pembelajaran konvensional yaitu pendekatan saintifik. Sehingga dapat disimpulkan model pembelajaran CLIS berbantuan media audio visual memiliki pengaruh yang signifikan terhadap kompetensi pengetahuan IPA siswa kelas V SD Gugus Dr. Soetomo Kecamatan Denpasar Selatan Tahun Pelajaran 2017/2018.

Hasil perhitungan omega square $\left(\omega^{2}\right)$ diperoleh $\omega^{2}=0,055$ dengan kriteria $\omega^{2}=0,01 \leq$ $0,055<0,09$ yang dapat disimpulkan bahwa dengan penerapan model pembelajaran CLIS 
berbantuan media audio visual memiliki persentase pengaruh (efektivitas) sebesar $5,5 \%$ yaitu dengan efek kecil. Hal ini menunjukkan bahwa sebesar $5,5 \%$ penerapan model pembelajaran CLIS berbantuan media audio visual menyebabkan perbedaan variansi skor kompetensi pengetahuan IPA.

Berdasarkan simpulan tersebut adapun saran yang dapat disampaikan yaitu, kepada guru disarankan lebih menambah wawasan dan pengetahuan tentang mengembangkan inovasi dan merancang pembelajaran untuk memberikan fasilitas berupa sumber belajar serta meningkatkan kualitas proses dan hasil pembelajaran dengan penerapan model pembelajaran, kepada kepala sekolah disarankan dapat menggunakan hasil penelitian ini sebagai pendukung sumber belajar guru dalam meningkatkan pembelajaran sehingga dapat meningkatkan mutu dan kualitas serta proses pembelajaran yang efektif dan efisien, kepada peneliti lain disarankan untuk menggunakan hasil penelitian ini sebagai acuan dalam melakukan penelitian selanjutnya pada tema dan kegiatan pembelajaran lainnya untuk memperoleh hasil yang lebih baik.

\section{Daftar Rujukan}

Agung, A. A. Gede. 2014. Metodelogi Penelitian Pendidikan. Malang: Aditya Media Publising.

Arikunto, Suharsimi. 2017. Dasar-Dasar Evaluasi Pendidikan. Jakarta: PT Bumi Aksara.

Dantes, Nyoman. 2017. Desain Eksperimen dan Analisis Data. Depok: PT. RajaGrafindo Persada.

Samatowa, Usman. 2016. Pembelajaran IPA di Sekolah Dasar. Jakarta: PT Indeks.

Setyosari, Punaji. 2015. Metode Penelitian Pendidikan dan Pengembangan. Jakarta: Prenadamedia Group.

Sugiyono. 2016. Metode Penelitian Pendidikan Pendekatan Kuantitatif, Kualitatif, dan $R$ \& D.Bandung: Alfabeta.

Susanto, Ahmad. 2016. Teori Belajar dan Pembelajaran di Sekolah Dasar. Jakarta: Prenadamedia Grup.

Wati, Ega Risma. 2016. Ragam Media Pembelajaran. Jakarta:Kata Pena.

Wisudawati, Asih Widi dan Eka Sulistyowati. 2015. Metodelogi Pembelajaran IPA. Jakarta: PT Bumi Aksara.

Yusuf, Muri. 2015. Asesmen dan Evaluasi Pendidikan. Jakarta: Prenadamedia Grup. 